\title{
Limbodessus bennetti sp. nov., the first stygobitic Dytiscidae (Coleoptera) from the Pilbara region of Western Australia
}

\author{
C.H.S. Watts ${ }^{1}$ and J. McRae ${ }^{2}$ \\ ${ }^{1}$ Entomology Section, South Australian Museum, North Terrace Adelaide, South Australia 5000, \\ Australia. Email: Chris.Watts@samuseum.sa.gov.au \\ 2 Bennelongia Environmental Consultants, 5 Bishop Street, Jolimont, WA 6014, Australia. \\ Email: jane.mcrae@bennelongia.com.au
}

\begin{abstract}
A new species of subterranean carnivorous water beetle, Limbodessus bennetti sp. nov. (Dytiscidae) is described from an alluvial aquifer in the northern Pilbara of Western Australia. The new species is most closely related, by morphological and DNA evidence, to species of stygobitic Limbodessus from the Yilgarn region of Western Australia.
\end{abstract}

KEYWORDS: Coleoptera, Dytiscidae, Limbodessus, stygobitic, Pilbara, Australia

\section{INTRODUCTION}

In the last few years a large number of small carnivorous water beetles (Dytiscidae) have been discovered living in underground aquifers in inland Australia (Watts and Humphreys, 2009 and references within). In most cases these are restricted to areas of calcrete which are cavernous and porous which allows a small but diverse fauna to live in them. Here we report the discovery of two specimens of a new Limbodessus Guignot, 1939 species from the Hamersley Range on the northern edge of the Pilbara region of Western Australia. Most calcretes in the Yilgarn region of Western Australia to the south of the Pilbara that have been sampled typically have two - three beetle species of the genera Limbodessus and/or Paroster Sharp, 1882 living in them. However, puzzlingly, no beetles have been found in the extensive aquifers of the Pilbara region abutting it to the north despite numerous studies and abundant food in the form of various Crustacea (Halse et al. 2014, in press). Morphologically and biochemically the new species is clearly related to stygobitic members of Limbodessus found in the Yilgarn.

\section{METHODS}

Specimens were collected while scraping for troglofauna using a weighted plankton net $(150 \mu \mathrm{m}$ mesh size) drawn through the water column to a depth of $1 \mathrm{~m}$. in a drill hole that penetrated the aquifer. The specimens were preserved in $100 \%$ ethanol. Colour illustrations of the habitus were made using a Leica M8 binocular microscope and a photomontage program. The resultant digital images were manipulated to a standard configuration and enhanced using Photoshop CS. Line drawings were prepared from photographic images.

The specimens are deposited in the collections of the Western Australian Museum, Perth (WAM).

\section{SYSTEMATICS}

\section{Family Dytiscidae Leach, 1815}

Tribe Bidessini Sharp, 1882

\section{Genus Limbodessus Guignot, 1939}

Limbodessus Guignot 1939: 52.

TYPE SPECIES

Hydroporus compactus Clark, 1862, by original designation.

\section{DIAGNOSIS}

Limbodessus can be distinguished from other dytiscid genera as follows: length $1.0-3.5 \mathrm{~mm}$, body elongate, without sutural striae, inner margins of metacoxal wings not strongly ridged. 


\section{Limbodessus bennetti sp. nov.}

Figures 1-4

\section{urn:Isid:zoobank.org:act:A5D48232-F8B5-4F05-846F- 4D108CBCB3B8}

\section{MATERIAL EXAMINED}

\section{Holotype}

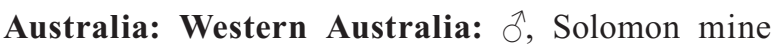
site, Hamersley Ranges, $22^{\circ} 07^{\prime} 15.9^{\prime \prime} \mathrm{S}, 117^{\circ} 44^{\prime} 05.7^{\prime \prime} \mathrm{E}$, 5 September 2011, J.S. Cocking, S.R. Bennett; original label data: "WA Solomon, Hamersley Ranges 220715.9 11744 5.7, 5/9/11, J. S. Cocking, S. R. Bennett” (WAM E83889).

\section{Paratype}

Australia: Western Australia: 1 , as for holotype (WAM E83890).

\section{DESCRIPTION}

Number examined $=2$.

Habitus: length $1.65 \mathrm{~mm}$; relatively flat, disc of elytra somewhat depressed, weakly constricted at junction of pronotum/elytra; elongate/oval, elytra slightly wider in middle; uniformly light testaceous; hindwing reduced, about a third length of elytron.

Head: a little narrower than elytra; smooth, shiny, punctures large about a puncture width apart, absent along posterior margin; subparallel in posterior half, widest in middle; eye remnant reduced to a single short suture. Antenna relatively thin, segments 1 and 2 beanshaped cylindrical, segment 3 a little shorter than segment 2 , narrower, narrowing towards base, segment 4 shorter, segments 5-10 approximately equal in shape, about as wide as long, weakly expanded at apex on inside; segment 11 almost as wide, about twice length of segment 10, each segment, except segment 1 , with some very small setae on inside apically. Maxillary palpus, rather stout, segment 4 as long as segments 1-3 combined.

Pronotum: about as wide as elytra; anterolateral angles projecting strongly forward; weakly constricted just before base, posterolateral angles almost square, overlying elytra somewhat; smooth, reticulation weak, punctures large but a bit smaller than those on head; basal plicae sharply impressed, straight, reaching about half way across pronotum, excavated on inside; with row of long setae laterally in anterior half.

Elytra: not fused, lacking inner ridges; a little wider in middle; smooth, finely reticulate, dull, punctures as
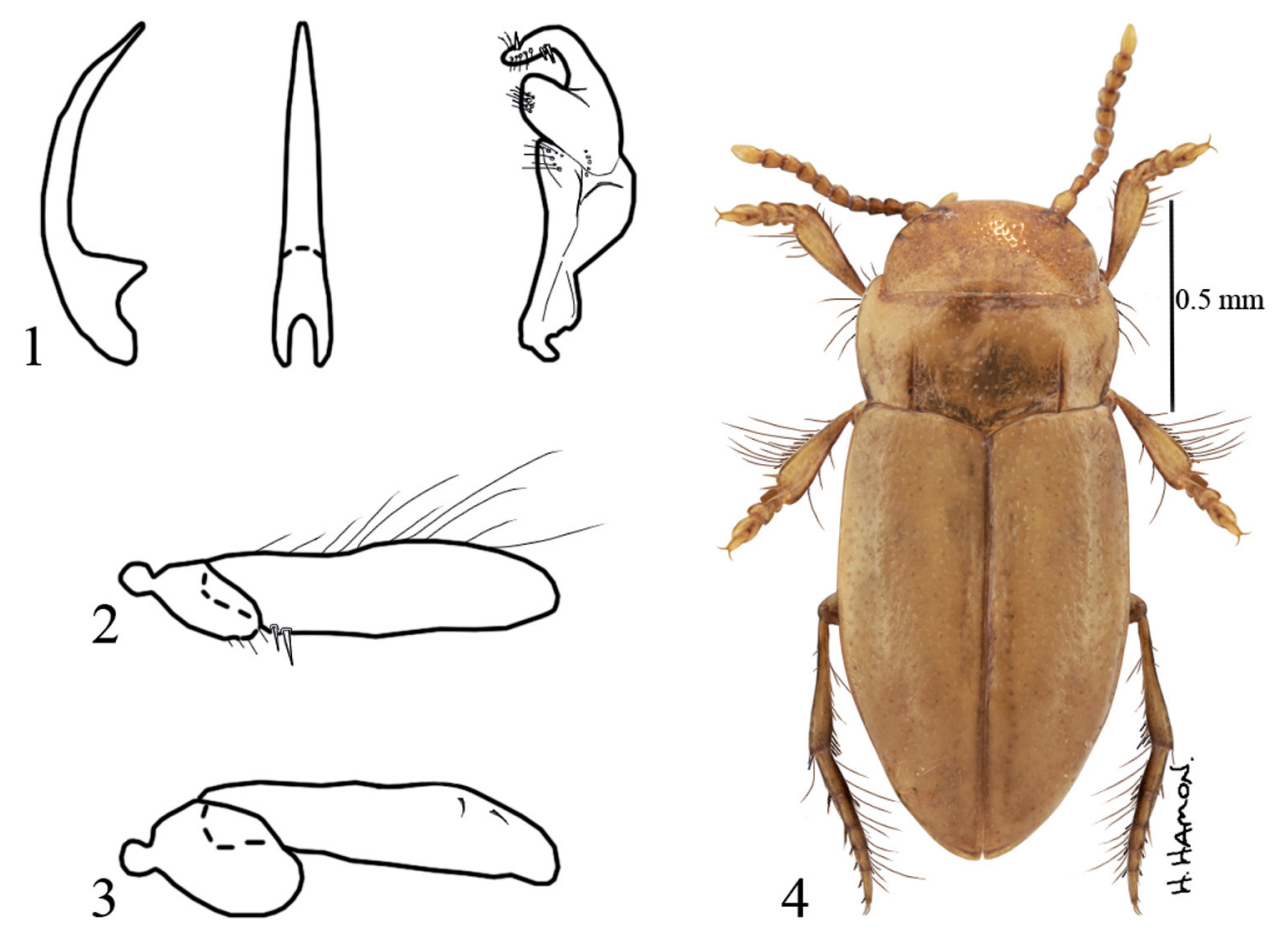

FIGURES 1-4 Limbodessus bennetti sp. nov.: 1, aedeagus, lateral view of medial lobe, ventral view of medial lobe and lateral view of paramere; 2, mesotrochanter and mesofemur; 3, metatrochanter and metafemur; 4, habitus. 
on pronotum, without row of larger punctures inwards from suture. Epipleuron weakly differentiated from rest of elytron, that portion of elytron visible ventrally, thin except at shoulders.

Ventral surface: prosternal process strongly narrowed between coxae, not reaching mesoventrite, apex arrowshaped, tip pointed, strongly arched in lateral view with highest point (viewed ventrally) between coxae. Anterior margin of mesoventrite in midline sculptured to accept pronotal process. Mesocoxae in contact at midline. Metaventrite wings narrow, rounded in midline behind. Metacoxal plates large, shiny, virtually nonreticulate, metacoxal lines obsolete; closely adpressed to ventrite 1 . Sutural lines between ventrites 1 and 2 reaching sides; ventrites 3-5 mobile, sparsely covered with small setabearing punctures, ventrites 3 and 4 with a central bunch of long setae.

Legs: pro-tibia elongate-triangular, widest near apex where it is about four times its basal width; protarsus moderately expanded, segment 1 nearly $2 \mathrm{x}$ as long as broad, segment 2 as wide as segment 1 and about a half its length, lobes well marked, segment 3 longer than segment 1 , about as wide, deeply bilobed, segment 4 very small, hidden within lobes of segment 3 , segment 5 narrow, cylindrical, about length of segment 3, segments 1-3 with adhesive setae; claws relatively short. Mesotrochanter elongate-rectangular with two setae on inner edge near base, the inner one half the length of other; mesofemur with two spines, the inner half length of the other, close together near base; mesotarsus similar to protarsus except a little more elongate. Metatrochanter large, broadly oval, tip rounded; metafemur relatively thin, lacking spines; metatibia narrow, weakly curved, widening towards apex; metatarsus rather stout, segment 1 longest, segment 5 a little longer than segment 4 , segments 1 and 2 in combination about as long as others; claws weak.

Male (Figures 1-3): little external difference between the sexes. Median lobe of aedeagus long, relatively thin, evenly narrowing towards tip, tip blunt; basal segment of paramere relatively broad, apical segment relatively long, broad, apical lobe long, thin, well separated from rest of segment, tip rounded.

\section{ETYMOLOGY}

Named after Sean Bennett, the collector of the specimens.

\section{DISCUSSION}

The small size, straight pronotal plicae, stout legs and antenna, round metatrochanters and, particularly, the strong dorsal punctures separates Limbodessus bennetti from all other known Limbodessus. In the key given in Watts and Humphreys (2009) it will run to couplet 17 but fits neither. Perhaps it best fits L. cunyuensis Watts and Humphreys but differs from this species in shape of parameres and penis and the small number of spines on the mesofemur as well as its strong punctures. Both specimens have a distinct depression on the disc of their elytra but it is possible that this is an artefact caused in some way by their handling. Sequence data based on the CO1 gene places Limbodessus bennetti nearest to, but distant from, L. narryerensis Watts and Humphreys (R. Leys pers. com.). Both the morphology and the sequence data clearly place Limbodessus bennetti within the Western Australian radiation of stygobitic Limbodessus centred on the Yilgarn.

The two specimens were collected during a troglofauna survey from a drill hole in an aquifer in Tertiary detritals in a valley of the Hamersley Range, together with isopods, amphipods and copepods. The depth to groundwater was $5 \mathrm{~m}$. No details of water chemistry were taken. This discovery adds to the sparse record of subterranean Dytiscidae from alluvial aquifers in Australia (Paroster peelensis Watts et al., 2008, Carabhydrus stephanieae Watts et al., 2007, and Paroster extraordinarius Leys et al., 2007), as distinct from the abundance of species from calcrete deposits in palaeodrainage channels in arid regions (Watts and Humphreys 2009). The distinct difference in the number of coexisting beetle species between alluvial aquifers and calcrete deposits presumably reflects differences in their ecology and possibly also their mode of speciation in turn driven by the large differences in the physical environments.

\section{ACKNOWLEDGEMENTS}

Howard Hamon skilfully enhanced the photographic images and prepared the line drawings. Remko Leys undertook the DNA analysis. Both are thanked for their contributions which greatly enhance the paper.

\section{REFERENCES}

Halse, S.A., Scanlon, M.D., Cocking, J.S., Barron, H.J., Richardson, J.B. and Eberhard, S.M. (2014, in press). Pilbara stygofauna: deep groundwater of an arid landscape contains globally significant radiation of biodiversity. Records of the Western Australian Museum, Supplement 78(2).

Leys R., Roundnew, B. and Watts, C.H.S. (2007). Paroster extraordinarius sp nov., a new groundwater diving beetle from the Flinders Ranges, with notes on other diving beetles from gravels in South Australia (Coleoptera: Dytiscidae). Australian Journal of Entomology 49: 66-72.

Watts, C.H.S. and Humphreys, W.F. (2009). Fourteen new Dytiscidae (Coleoptera) of the genera Limbodessus Guignot, Paroster Sharp, and Exocelina Broun from underground waters in Australia. Transactions of the Royal Society of South Australia 133: 62-107.

Watts, C.H.S., Hancock, P.J. and Leys, R. (2007). A stygobitic Carabhydrus Watts (Dytiscidae, Coleoptera) from the Hunter Valley in New South Wales, Australia. Australian Journal of Entomology 46: 56-59.

Watts, C.H.S., Hancock, P.J. and Leys, R. (2008). Paroster peelensis sp. nov.: a new stygobitic water beetle from alluvial gravels in northern New South Wales (Coleoptera: Dytiscidae). Australian Journal of Entomology 47: 227-231.

MANUSCRIPT RECEIVED 1 AUGUST 2013; ACCEPTED 25 NOVEMBER 2013. 